University of Wollongong

Research Online

Faculty of Informatics - Papers (Archive)

Faculty of Engineering and Information

Sciences

$1-1-2009$

\title{
Long-term liming regime increases prime lamb production on acid soils
}

G Chen

Yunnan University

G D. Li

Wagga Wagga Agricultural Institute

M K. Conyers

Wagga Wagga Agricultural Institute

B R. Cullis

University of Wollongong, bcullis@uow.edu.au

Follow this and additional works at: https://ro.uow.edu.au/infopapers

Part of the Physical Sciences and Mathematics Commons

\section{Recommended Citation}

Chen, G; Li, G D.; Conyers, M K.; and Cullis, B R.: Long-term liming regime increases prime lamb production on acid soils 2009, 221-234.

https://ro.uow.edu.au/infopapers/2078

Research Online is the open access institutional repository for the University of Wollongong. For further information contact the UOW Library: research-pubs@uow.edu.au 


\title{
Long-term liming regime increases prime lamb production on acid soils
}

\author{
Abstract \\ Prime lamb live weight response to lime application on pasture was measured in a grazing experiment in \\ the high rainfall zone of the southwestern slopes of New South Wales, Australia. The pastures were limed \\ every 6 years over 15 years. First cross South African Meat Merino lambs were used as test animals. \\ Preand post-grazing pasture dry matter (DM) yield, botanical composition, feed quality and lamb live \\ weight were monitored over 12 weeks in 2007. Results showed that liming significantly increased \\ pastureDMyield of high quality species and improved overall pasture quality due to increased digestibility \\ and metabolic energy content. As a result, the limed perennial and annual pastures carried $24.0 \%(3.6$ \\ lambs ha-1) and $29.0 \%$ (4.4 lambs ha-1)more stock than the unlimed perennial and annual pastures, \\ respectively. Averaged across pasture types, the limed pastures produced $30.6 \%$ (131 kg ha-1) more lamb \\ live weight gain than the unlimed pastures over 12 weeks. The live weight gain varied between grazing \\ cycles depending on the availability of feed-on-offer and feed quality,whichwere closely related to the \\ rainfall pattern. The perennial pastures did not show any advantage in animal production over annual \\ pastures during the experimental period due to lack of moisture in the deep soil profile because of severe \\ drought in the previous year. More seasons with normal or above average rainfall are needed to compare \\ animal production on perennial pastures and annual pastures to investigate the advantage of perennial \\ pastures in animal production.

\section{Keywords} \\ prime, term, liming, regime, increases, production, acid, soils, long, lamb \\ Disciplines \\ Physical Sciences and Mathematics

\section{Publication Details} \\ Chen, G., Li, G. D., Conyers, M. K. \& Cullis, B. R. (2009). Long-term liming regime increases prime lamb \\ production on acid soils. Experimental Agriculture, 45 (2), 221-234.
}




\title{
LONG-TERM LIMING REGIME INGREASES PRIME LAMB PRODUGTION ON AGID SOILS
}

\author{
By G. CHEN, G. D. LI $\dagger, \ddagger$ M. K. CONYERS $\dagger$ and B. R. CULLIS $\dagger$ \\ College of Animal Science, Nunnan Agricultural University, Kunming, Funnan 650201, China and \\ $\dagger$ E H Graham Centre for Agricultural Innovation (Alliance between NSW Department of Primary \\ Industries and Charles Sturt University), Wagga Wagga Agricultural Institute, PMB, Wagga \\ Wagga, NSW 2650, Australia
}

(Accepted 28 November 2008)

\begin{abstract}
SUMMARY
Prime lamb live weight response to lime application on pasture was measured in a grazing experiment in the high rainfall zone of the southwestern slopes of New South Wales, Australia. The pastures were limed every 6 years over 15 years. First cross South African Meat Merino lambs were used as test animals. Preand post-grazing pasture dry matter (DM) yield, botanical composition, feed quality and lamb live weight were monitored over 12 weeks in 2007. Results showed that liming significantly increased pasture DM yield of high quality species and improved overall pasture quality due to increased digestibility and metabolic energy content. As a result, the limed perennial and annual pastures carried $24.0 \%\left(3.6 \mathrm{lambs}^{-1} \mathrm{~h}^{-1}\right)$ and $29.0 \%$ (4.4 lambs ha $\left.{ }^{-1}\right)$ more stock than the unlimed perennial and annual pastures, respectively. Averaged across pasture types, the limed pastures produced $30.6 \%\left(131 \mathrm{~kg} \mathrm{ha}^{-1}\right)$ more lamb live weight gain than the unlimed pastures over 12 weeks. The live weight gain varied between grazing cycles depending on the availability of feed-on-offer and feed quality, which were closely related to the rainfall pattern. The perennial pastures did not show any advantage in animal production over annual pastures during the experimental period due to lack of moisture in the deep soil profile because of severe drought in the previous year. More seasons with normal or above average rainfall are needed to compare animal production on perennial pastures and annual pastures to investigate the advantage of perennial pastures in animal production.
\end{abstract}

\section{INTRODUGTION}

Prime lamb production is becoming one of the most important and profitable agricultural enterprises in southeastern Australia (Kopke et al., 2008), and a growing number of sheep producers consider this to be their primary activity. A survey conducted by Hooper et al. (2003) in 1999-2000 showed that more than $20 \%$ of farm income came from prime lamb sales for $70 \%$ of prime lamb producers in New South Wales (NSW) and Victoria, Australia. However, soil acidity is one of most limiting factors for agricultural production, including prime lambs, in the high rainfall region of southeastern Australia.

Lime application is the most commonly used solution to soil acidification and constant lime applications will be needed if agricultural production is to continue in much of the high rainfall zone of Australia. However, the low profitability of grazing enterprises and relatively high cost of lime means that economically viable responses 
from plant and animal production to lime will be more difficult to demonstrate experimentally in grazing areas than in cropping areas (Scott et al., 2000). There is a need to predict pasture response to lime applications and to identify the economic value of any benefit resulting from gains in animal production on those pastures.

Pasture dry matter (DM) yield responses to lime have been reported in southern Australia, varying from nil to $100 \%$ (Hochman et al., 1990; Ridley and Coventry, 1992; Yeates et al., 1984). In contrast, lime responses of $10 \%$ (up to $1.5 \mathrm{t} \mathrm{ha}^{-1}$ ) were more common in the North Island of New Zealand (Bircham and Crouchley, 1976; Edmeades et al., 1984; Shannon et al., 1984). Furthermore, liming often improves the pasture feeding value by favouring desired and suppressing undesired species (Bircham and Crouchley, 1976; Li et al., 2003).

Despite the documented pasture responses, there is limited research on animal responses to liming pastures. Li et al. (2006) reported that Merino wethers produced significantly more greasy wool and greater live weight gain when grazed on limed pastures compared to those grazed on unlimed pastures on the southwestern slopes of NSW. However, there are no reports on lamb growth or live weight responses to limed pastures in the literature. The objective of this study was to compare the effect of liming pastures on animal production (measured as lamb live weight gain) on both annual and perennial pastures.

\section{MATERIALS AND METHODS}

\section{Site description}

The experiment was conducted on the property Brooklyn, operated by the Hurstmead Pastoral Co. Pty Ltd, at Book Book $\left(35^{\circ} 23^{\prime} \mathrm{S}, 147^{\circ} 30^{\prime} \mathrm{E}\right), 40 \mathrm{~km}$ southeast of Wagga Wagga, NSW, Australia. The soil is a subnatric yellow sodosol, Typic Fragiochrept in USDA taxonomy, with some red phases over the site. The soil is highly acidic to depth with a strong texture contrast or duplex nature, loamy sand to sandy loam A horizon overlaying a clay $\mathrm{B}$ horizon. When the experiment started in 1992 , the average $\mathrm{pH}$ in $0.01 \mathrm{M} \mathrm{CaCl}_{2}\left(\mathrm{pH}_{\mathrm{Ca}}\right)$ in $0-10 \mathrm{~cm}$ soil depth was 4.0 and subsurface $\mathrm{pH}_{\mathrm{Ca}}$ was below 4.5 to at least $20 \mathrm{~cm}$, typical of the more acidified soils of the region.

\section{Experimental design}

Two types of pastures (perennial and annual) were established in 1992, and resown in 2004. The perennial pasture was sown to phalaris (Phalaris aquatica) cvv. Australian $\left(0.5 \mathrm{~kg} \mathrm{ha}^{-1}\right)$ and Holdfast $\left(1.0 \mathrm{~kg} \mathrm{ha}^{-1}\right)$, cocksfoot (Dactylis glomerata) cv. Currie (1.0 $\left.\mathrm{kg} \mathrm{ha}^{-1}\right)$, lucerne (Medicago sativa) cv. Aurora $\left(3.0 \mathrm{~kg} \mathrm{ha}^{-1}\right)$ and subterranean clover (Trifolium subterraneum) cvv. Junee, Goulburn and Trikkala $\left(1.5 \mathrm{~kg} \mathrm{ha}^{-1}\right.$ each). The annual pasture was sown to annual ryegrass (Lolium rigidum) $\mathrm{cv}$. Wimmera $\left(2.0 \mathrm{~kg} \mathrm{ha}^{-1}\right)$ and subterranean clover cvv. Junee, Goulburn and Trikkala (2.5 kg ha ${ }^{-1}$ each).

Limed treatments were imposed on both pasture types. The limed treatments were limed 3-4 times as per the experimental protocol since 1992 (Li et al., 2001). There were 12 plots under the limed treatments and six plots under the unlimed treatments 
for each pasture type, giving 36 plots in total. Plot size was $30 \mathrm{~m} \times 45 \mathrm{~m}$. Further details of the experimental design and lime regime were reported in Li et al (2001).

\section{Sheep selection and grazing management}

First cross lambs of South African Meat Merino (SAMM) rams with Merino ewes, 6 months old, were used as test animals. Twelve groups of lambs with a starting live weight of 33-35 kg were selected in mid-August in 2007. Each group of sheep was rotationally grazed on a set of three plots within a treatment. For a given plot, the pasture was grazed 1 week and rested 2 weeks in a grazing cycle.

In each group, there were 10 lambs as core sheep and 5-10 lambs as extra sheep, which were used to adjust the stocking rate when necessary. The stocking rate was always the same within a treatment, but varied between the treatments. Stocking rates were adjusted at the start of each grazing cycle according to the pasture availability and sheep live weight with the objective of achieving equal grazing pressure and animal production per head on all treatments.

\section{Measurements}

Sheep were rotationally grazed on the site for 12 weeks from 22 August to 14 November in 2007. All the core sheep were weighed every 3 weeks. The fasted live weight (16-24 hours) was taken at the start and end of the experiment.

Pre- and post-grazing pasture DM yield was measured using a falling plate meter (Arborline, Hamilton, Victoria, Australia), with 20 readings in each plot. The falling plate meter was calibrated against quadrat cuts for each pasture type in each grazing cycle. The botanical composition of the pasures was measured three times (at the start, middle and end of the experiment) using an improved dry-weight-rank method, with 20 measurements in each plot.

Twenty grab samples, bulked, were taken from each plot for a feed quality test three times (at the start, middle and end) during the experiment. Herbage samples were airdried at $45{ }^{\circ} \mathrm{C}$ for 48 hours immediately after removal from the field, then ground to pass through 0.8-mm mesh. Crude protein (CP, \%), digestible organic matter content (DOMC, \%), acid detergent fibre (ADF, \%) and neutral detergent fibre (NDF, \%) were analysed using the near-infrared technique $\left(\right.$ Bruker MPA $^{\mathrm{TM}}$ run with Omnion version 5.1, made by Bruker Optics). Metabolic energy (ME, $\mathrm{MJ} \mathrm{kg}^{-1} \mathrm{DM}$ ) was calculated from DOMC.

\section{Sheep health care}

When sheep were introduced to the site, they were drenched with Triton (ivermectin at $0.8 \mathrm{~g} \mathrm{l}^{-1}$, levamisole at $25.5 \mathrm{~g} \mathrm{l}^{-1}$ and Albendazole at $20 \mathrm{~g} \mathrm{l}^{-1}$ ) at $9 \mathrm{ml}$ per lamb for internal parasites, and administered orally one Permatrace cobalt pellet (cobalt oxide $300 \mathrm{~g} \mathrm{~kg}^{-1}$ ) and one selenium pellet (elemental selenium $50 \mathrm{~g} \mathrm{~kg}^{-1}$ ) to prevent phalaris staggers and the PE (polioencephalomalacia-like) form of sudden death. Sheep were crutched as required and sprayed with two strips of Vetrazin (Cyromazine $60 \mathrm{~g} \mathrm{l}^{-1}$ at $44 \mathrm{ml} \mathrm{sheep}^{-1}$ ) when necessary to reduce the incidence of fly-strike. Fly-struck sheep 
Table 1. Long term rainfall and monthly (2004-2007) rainfall (mm) at Book Book, New South Wales, Australia.

\begin{tabular}{lrrrrr}
\hline Month & 2004 & 2005 & 2006 & 2007 & LTR $^{\dagger}$ \\
\hline January & 19.4 & 26.1 & 29.6 & 17.0 & 34.8 \\
February & 7.0 & 40.0 & 0.4 & 64.2 & 40.0 \\
March & 13.4 & 11.3 & 20.2 & 75.2 & 42.5 \\
April & 16.0 & 24.0 & 27.2 & 59.4 & 35.9 \\
May & 50.0 & 3.2 & 8.4 & 83.8 & 49.4 \\
June & 92.4 & 135.4 & 47.8 & 21.8 & 59.0 \\
July & 58.2 & 78.8 & 57.2 & 76.4 & 62.4 \\
August & 74.6 & 87.0 & 19.2 & 32.6 & 55.2 \\
September & 53.6 & 119.8 & 28.8 & 14.2 & 59.0 \\
October & 22.6 & 88.8 & 6.4 & 70.8 & 63.4 \\
November & 93.6 & 34.8 & 42.0 & 138.0 & 57.5 \\
December & 39.0 & 93.7 & 1.2 & 111.0 & 47.8 \\
Total & 539.8 & 742.9 & 288.4 & 764.4 & 606.9 \\
\hline
\end{tabular}

${ }^{\dagger}$ LTR, mean of long term rainfall from 1992 to 2007.

were treated with Di-jet (Daizinon $200 \mathrm{~g} \mathrm{l}^{-1}$ ) at $1 \mathrm{ml} \mathrm{l}^{-1}$ solution. In September 2007, there was an outbreak of foot-rot on the property. All sheep were examined for the infection and had their feet pared; their feet were then bathed weekly with a $2 \%$ zinc sulfate treatment.

\section{Data analysis}

Sheep live weight was analysed on a per head and per hectare basis. The live weight production per hectare for each grazing cycle was derived from the average live weight gain of each group of core sheep multiplied by the stocking rate used in each grazing cycle, then calculated as daily live weight gain per hectare. The total live weight production for a given treatment was the sum of live weight gain from four grazing cycles. A linear mixed model was used to analyse the sheep responses to pasture type (perennial v. annual pastures) and the lime treatments (limed v. unlimed). This model included random effects that accounted for the design and randomization structure as well as accounting for the serial dependence in the sequences of repeated measurements on each plot and sheep. All analyses were conducted with the statistical package ASReml (Gilmour et al., 2006).

\section{RESULTS}

\section{Rainfall}

The long-term rainfall is $606.9 \mathrm{~mm}$ at the experiment site. The total rainfall in 2007 was $764.4 \mathrm{~mm}$, but it was unevenly distributed (Table 1). It was extremely dry in August and September in 2007. A one in one hundred year drought occurred in 2006 with total annual rainfall of only $288.4 \mathrm{~mm}$, resulting in very dry soil profile prior to the experimental period. 
Table 2. Wald statistics of main effects and their interactions for pre- and post grazing pasture dry matter (DM) yield at Book Book, New South Wales, Australia.

\begin{tabular}{|c|c|c|c|c|}
\hline \multirow[b]{2}{*}{ Terms in model ${ }^{\dagger}$} & \multicolumn{2}{|c|}{ Total pasture DM yield } & \multicolumn{2}{|c|}{ High quality feed ${ }^{\ddagger}$} \\
\hline & Pre-grazing & Post-grazing & Pre-grazing & Post-grazing \\
\hline \multicolumn{5}{|l|}{ Block $\times$ plot } \\
\hline Pasture & 0.01 & 2.23 & 0.17 & 0.27 \\
\hline Lime & 0.29 & 3.54 & $13.91^{* * *}$ & $17.58^{* * *}$ \\
\hline Pasture $\times$ lime & 0.50 & 0.08 & 1.09 & 0.39 \\
\hline \multicolumn{5}{|l|}{ Block $\times$ plot $\times$ cycle } \\
\hline Cycle & 0.04 & 0.75 & 0.06 & 1.11 \\
\hline Cycle $\times$ pasture & 1.73 & 0.05 & 3.10 & 0.10 \\
\hline Cycle $\times$ lime & 2.31 & 0.18 & 0.86 & 0.46 \\
\hline Cycle $\times$ pasture $\times$ lime & 0.25 & 0.73 & 0.04 & 0.13 \\
\hline
\end{tabular}

\section{Pre- and post-grazing pasture DM yield}

Lime had no significant effect on total pasture DM yield during the experimental period, but significantly increased the yield of high quality feed on both perennial and annual pastures $(p<0.001$, Table 2$)$. High quality feed was defined as pasture DM from highly nutritive species excluding DM from silvergrass, sorrel and other broadleaf weeds. During the 12-week grazing period (four grazing cycles), there were no differences between pasture type, grazing cycle or the associated interactions in either pre- or post-grazing total pasture DM yield and high quality feed.

There was more feed-on-offer on the limed than unlimed treatments over the experimental period (Figure 1a). On the limed treatments, the pasture DM yield was highest at the end of September $\left(2.8 \mathrm{t} \mathrm{ha}^{-1}\right)$, and lowest in the middle of November $\left(2.2 \mathrm{t} \mathrm{ha}^{-1}\right)$. In contrast, on the unlimed treatments, the highest pasture DM yield was $2.3 \mathrm{t} \mathrm{ha}^{-1}$ at the end of September, but the lowest was $1.5 \mathrm{t} \mathrm{ha}^{-1}$ in the middle of August.

There was no significant difference in feed-on-offer between perennial and annual pastures. There was more post-grazing pasture DM yield on the limed treatments than unlimed treatments, but less difference when compared to pre-grazing pasture DM yield (Figure 1b).

\section{Pasture botanical composition}

Lime application had a significant effect on the botanical composition of both perennial and annual pastures (Figure 2). In the perennial pastures, lime application significantly increased the proportion of lucerne $(p<0.01)$, and subterranean clover in the sward $(p<0.001)$, but not phalaris, cocksfoot or ryegrass. In the annual pastures, lime application increased the proportion of subterranean clover in the sward $(p<0.001)$, but not annual ryegrass. Subterranean clover content was up to 

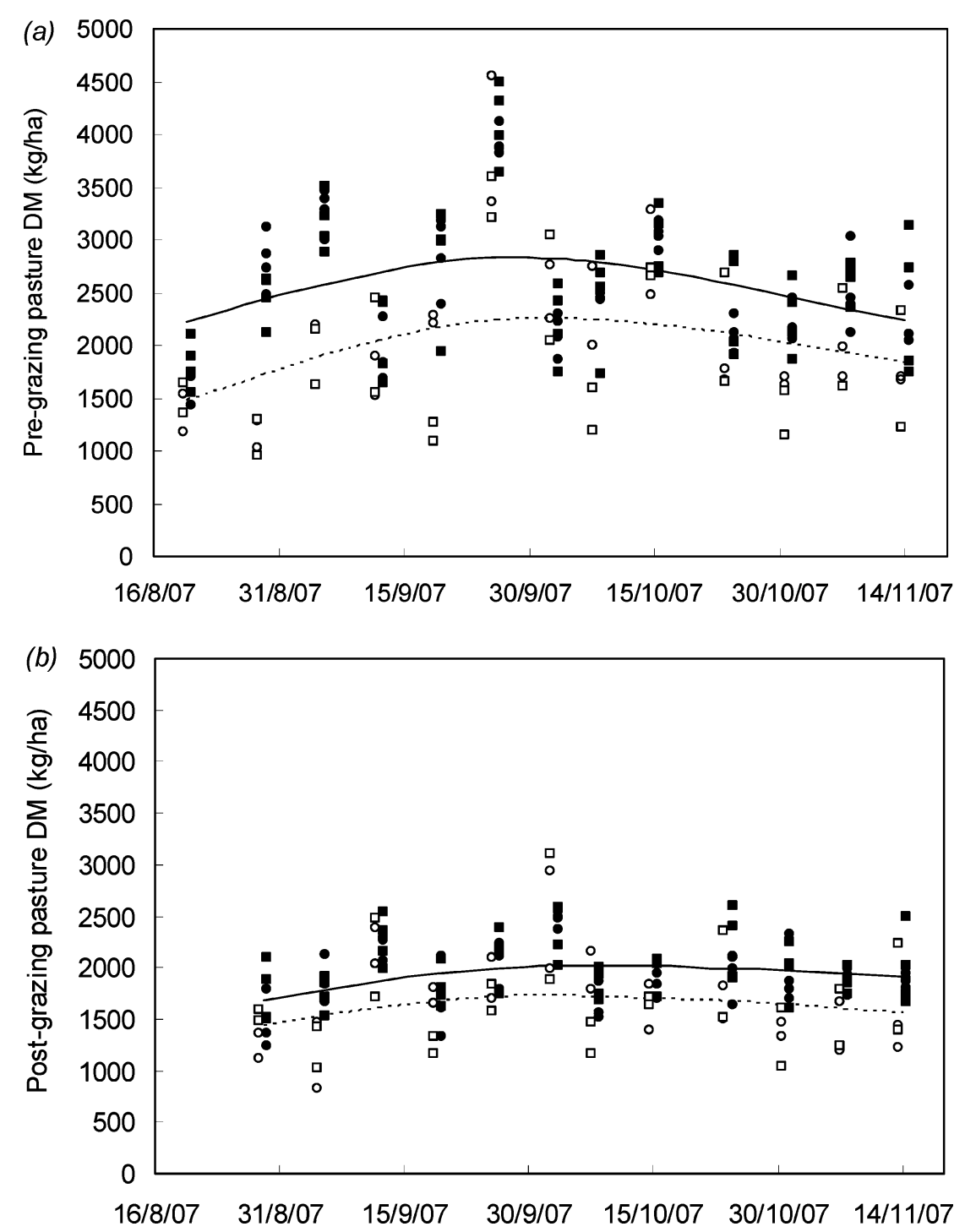

Figure 1. Pasture DM yield of high quality species at $(a)$ pre-grazing and $(b)$ post-grazing for the limed and unlimed annual pastures (• and o) and perennial pastures ( $\bullet$ and $)$, respectively at Book Book, New South Wales, Australia. Solid and dashed lines are the fitted splines for the limed and unlimed pastures, respectively.

$72 \%$ for annual pastures and $59 \%$ for perennial pasture on the limed treatments, whereas subterranean clover contents was much lower on both annual $(56 \%)$ and perennial pasture $(46 \%)$ under the unlimed treatments. In both pasture types, there was significantly more Vulpia spp. and sorrel on the unlimed than limed treatments $(p<0.001)$. The proportion of barley grass, an acid-sensitive species that provides high quality feed for animals before maturity, was significantly higher on the limed than on the unlimed treatments $(p<0.001)$. 

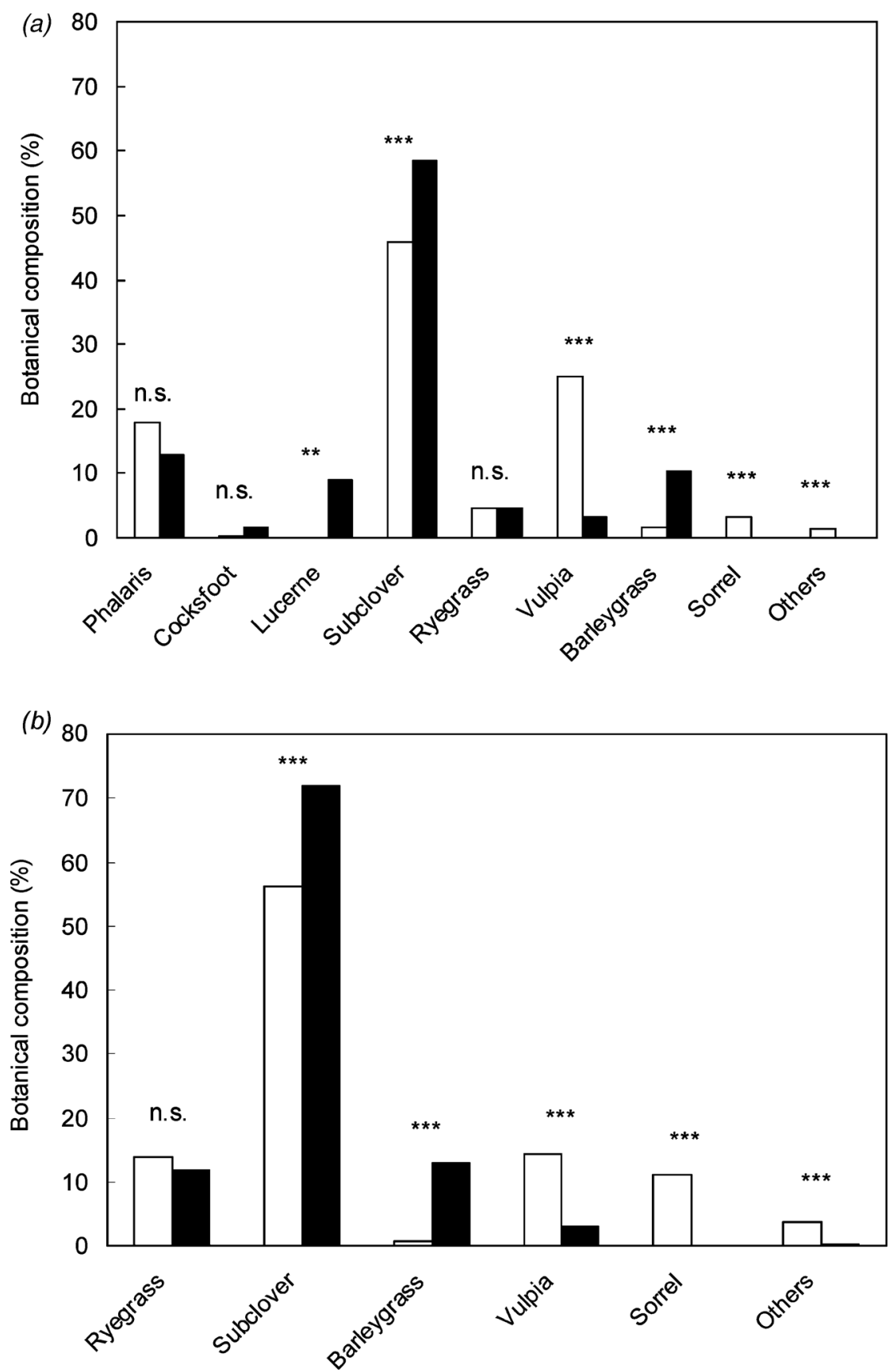

Figure 2. The botanical composition of $(a)$ perennial pastures and $(b)$ annual pastures in August 2007 at Book Book, New South Wales, Australia. Open bars, unlimed pastures; solid bars, limed pastures. ${ }^{* *} p<0.01 ;{ }^{* * *} p<0.001 ;$ n.s. not significant. 
Table 3. Feed quality of annual pastures (AP) and perennial pastures (PP) with $(+)$ and without lime $(-)$ at Book Book, New South Wales, Australia.

\begin{tabular}{|c|c|c|c|}
\hline Sample time & Vegetative & Anthesis & Mature \\
\hline \multicolumn{4}{|c|}{ Crude protein $(\%)$} \\
\hline $\mathrm{AP}-$ & 29.9 & 24.9 & 15.6 \\
\hline $\mathrm{AP}+$ & 28.7 & 26.2 & 15.7 \\
\hline $\mathrm{PP}-$ & 28.9 & 23.9 & 15.7 \\
\hline $\mathrm{PP}+$ & 29.7 & 25.0 & 19.8 \\
\hline s.e.d. $(d . f .=31)$ & 0.55 & 1.40 & 1.30 \\
\hline \multicolumn{4}{|c|}{ Digestible organic matter content $(\%)$} \\
\hline $\mathrm{AP}-$ & 66.5 & 65.0 & 52.5 \\
\hline $\mathrm{AP}+$ & 66.3 & 65.6 & 54.6 \\
\hline $\mathrm{PP}-$ & 65.6 & 64.0 & 53.2 \\
\hline $\mathrm{PP}+$ & 66.3 & 65.1 & 57.3 \\
\hline s.e.d. $($ d.f. $=31)$ & 0.61 & 0.50 & 0.97 \\
\hline \multicolumn{4}{|c|}{ Metabolic energy $\left(\mathrm{MJ} \mathrm{kg}^{-1} \mathrm{DM}\right)$} \\
\hline $\mathrm{AP}-$ & 10.5 & 10.2 & 7.7 \\
\hline $\mathrm{AP}+$ & 10.5 & 10.3 & 8.1 \\
\hline $\mathrm{PP}-$ & 10.3 & 10.0 & 7.8 \\
\hline $\mathrm{PP}+$ & 10.5 & 10.2 & 8.6 \\
\hline s.e.d. $($ d.f. $=31)$ & 0.12 & 0.10 & 0.20 \\
\hline \multicolumn{4}{|c|}{ Acid detergent fibre (\%) } \\
\hline $\mathrm{AP}-$ & 23.2 & 23.0 & 34.3 \\
\hline $\mathrm{AP}+$ & 23.0 & 23.6 & 32.4 \\
\hline $\mathrm{PP}-$ & 24.2 & 24.8 & 33.6 \\
\hline $\mathrm{PP}+$ & 23.7 & 23.9 & 30.2 \\
\hline s.e.d. $($ d.f. $=31)$ & 0.72 & 0.60 & 1.10 \\
\hline \multicolumn{4}{|c|}{ Neutral detergent fibre $(\%)$} \\
\hline $\mathrm{AP}-$ & 38.1 & 42.5 & 58.0 \\
\hline $\mathrm{AP}+$ & 39.4 & 41.7 & 58.6 \\
\hline $\mathrm{PP}-$ & 41.5 & 43.6 & 58.6 \\
\hline $\mathrm{PP}+$ & 39.5 & 42.1 & 55.9 \\
\hline s.e.d. $($ d.f. $=31)$ & 1.00 & 0.91 & 1.59 \\
\hline
\end{tabular}

\section{Pasture feed quality}

CP, DOMC and ME decreased gradually, but NDF and ADF increased over time as plants matured (Table 3). There were significant pasture $\times$ lime interactions in CP $(p<0.05)$ during vegetative and mature stages. CP content was $28.7-29.9 \%$ during vegetative stage and $23.9-26.2 \%$ at anthesis, but dropped to around $15.6 \%$ during the mature stage for all treatments except for the limed perennial pastures where CP was $19.8 \%$ at maturity.

Limed pastures had significantly higher DOMC and ME at anthesis $(p<0.05)$ and the mature stage $(p<0.001)$ than the unlimed pastures, but there was no difference at the vegetative stage (Table 3). Perennial pastures had lower DOMC and ME at anthesis $(p<0.05)$, but higher DOMC and ME during the mature stage $(p<0.01)$ than annual pastures (Table 3$)$. At maturity, there were significantly higher $(p<0.05)$ $\mathrm{NDF}$ and ADF for the annual pastures than the perennial pastures. The unlimed pastures had significantly higher $(p<0.05)$ ADF than the limed pastures (Table 3$)$. 
Table 4. Wald statistics of main effects and their interactions for live weight and live weight gain at Book Book, New South Wales, Australia.

\begin{tabular}{lcc}
\hline Terms in model & \multicolumn{2}{c}{ Live weight gain } \\
\hline & $\left(\mathrm{g} \mathrm{head}^{-1}\right)$ & $\left(\mathrm{kg} \mathrm{ha}^{-1}\right)$ \\
Block $\times$ plot & 0.89 & $5.79^{*}$ \\
$\quad$ Pasture & $7.72^{* *}$ & $17.81^{* * *}$ \\
Lime & 0.25 & 1.74 \\
Pasture $\times$ lime & & \\
Block $\times$ plot $\times$ cycle & $123.04^{* * *}$ & $129.97^{\S}$ \\
Cycle & 2.23 & $5.08^{* *}$ \\
Cycle $\times$ pasture & 0.33 & $10.80^{* * *}$ \\
Cycle $\times$ lime & 0.91 & 1.80 \\
Cycle $\times$ pasture $\times$ lime & \\
\hline Cycle: grazing cycles, 1-week grazing and 2-week resting. \\
$* p<0.05 ; * *<0.01 ; * * *<0.001$.
\end{tabular}

However, no significant difference was observed in NDF between unlimed and limed pastures.

\section{Lamb live weight changes}

During the 12-week grazing period, lamb live weight increased substantially from 33.9 to $48.0 \mathrm{~kg}$ per head (Figure 3). There was no difference in live weight gain per head between pasture types, but there was significant difference in live weight gain per head between limed and unlimed treatments due to greater grazing pressure on the limed treatment as expected (Table 4). During first two cycles, the daily live weight gain was over $213 \mathrm{~g} \mathrm{head}^{-1}$, up to $286 \mathrm{~g} \mathrm{head}^{-1}$ at the first cycle (Table 5). At cycle 4, lambs on the limed pastures lost weight due to low pasture feed-on-offer (Figure 1) although stocking rates on the limed treatments were dropped to a similar level to those on the unlimed treatments (Table 5).

\section{Live weight production per hectare}

Averaged across four grazing cycles, limed perennial and annual pastures carried $24.0 \%\left(3.6 \mathrm{lambs} \mathrm{ha}^{-1}\right)$ and 29.0\% (4.4 lambs ha $\left.{ }^{-1}\right)$ more stock than the unlimed perennial and annual pastures, respectively (Table 5). As a result, there was a significant difference in live weight gain per hectare between the limed and unlimed treatments $(p<0.001)$ and between perennial and annual pastures $(p<0.05)$. During the first two grazing cycles, the limed pastures produced significantly more live weight than unlimed pastures (232 v. $153 \mathrm{~kg} \mathrm{ha}^{-1}$ ), and annual pastures produced significantly more live weight than perennial pastures (210 v. $\left.175 \mathrm{~kg} \mathrm{ha}^{-1}\right)$ (Table 5). At cycle 4, the reverse was true, whereas there was no significant difference in live weight gain per hectare between lime treatments or pasture types at cycle 3 (Table 5). 
Table 5. Average stocking rate (lambs ha ${ }^{-1}$ ), daily live weight gain $\left(\mathrm{g} \mathrm{head}^{-1}\right)$ and live weight gain $\left(\mathrm{kg} \mathrm{ha}^{-1}\right)$ from annual pastures (AP) and perennial pastures $(\mathrm{PP})$ with $(+)$ and without lime $(-)$ for each grazing cycle at Book Book, New South Wales. Australia.

\begin{tabular}{lcccr}
\hline Treatments & Cycle $1^{\dagger}$ & Cycle 2 & Cycle 3 & Cycle 4 \\
\hline Stocking rate $\left(\right.$ lambs ha $\left.^{-1}\right)$ & & & & \\
AP- & 24.7 & 29.6 & 29.6 & 29.6 \\
AP+ & 42.0 & 46.8 & 41.9 & 29.6 \\
PP- & 24.7 & 29.6 & 32.1 & 32.1 \\
PP+ & 39.5 & 44.4 & 37.0 & 34.6 \\
Daily live weight gain $\left(\mathrm{g} \mathrm{head}^{-1}\right)$ & & & \\
AP- & 278 & 267 & 190 & 4 \\
AP+ & 286 & 220 & 128 & -41 \\
PP- & 249 & 224 & 155 & 27 \\
PP+ & 213 & 215 & 145 & -24 \\
s.e.d. $($ d.f. = 346) & 32.8 & 32.2 & 31.9 & 32.6 \\
Live weight gain (kg ha $\left.{ }^{-1}\right)$ & & & \\
AP- & 151 & 166 & 118 & 2 \\
AP+ & 306 & 216 & 119 & -25 \\
PP- & 140 & 152 & 104 & 27 \\
PP+ & 201 & 206 & 113 & -14 \\
s.e.d. $($ d.f. = 346) & 25.4 & 25.2 & 25.2 & 26.9 \\
\hline${ }^{\dagger}$ Cycle: grazing cycles, 1-week grazing and 2-week resting. &
\end{tabular}

DISCUSSION

\section{Prime lamb production in response to liming pastures}

The most important finding from the present study was that both perennial and annual pastures with a liming history of 15 years significantly increased prime lamb production on a highly acidic site in the high rainfall zone of the southwestern slopes of NSW, Australia. Averaged across pasture types, limed pastures produced $30.6 \%\left(131 \mathrm{~kg} \mathrm{ha}^{-1}\right)$ more lamb live weight gain than unlimed pastures $(p<0.001)$ using first cross SAMM lambs over a 12-week grazing period. To our knowledge, this is the first study to test and compare prime lamb live weight response to lime application on pastures on highly acidic soils. At the same site, Li et al. (2006) reported that the limed perennial pastures produced $27 \%$ more live weight gain than the unlimed perennial pastures, whereas the limed annual pastures produced $34 \%$ more live weight gain than unlimed annual pastures over 6 years using 15-18 month-old Merino wethers. Bircham et al. (1977) found that the mean percentage live weight response to lime of ewes grazed at a high stocking rate was $10.3 \%$ over 5 years on a yellow-grey earth on the Wairarapa Plains in North Island, New Zealand.

The greater animal production on the limed pastures is primarily attributed to better feed quality rather than total pasture quantity as no difference in total pasture DM yield production was detected between the treatments. However, there was significantly more high quality feed on the limed pastures, as evidenced by the higher nutritive value of feed-on-offer compared to the unlimed pastures (Table 3). This is most 

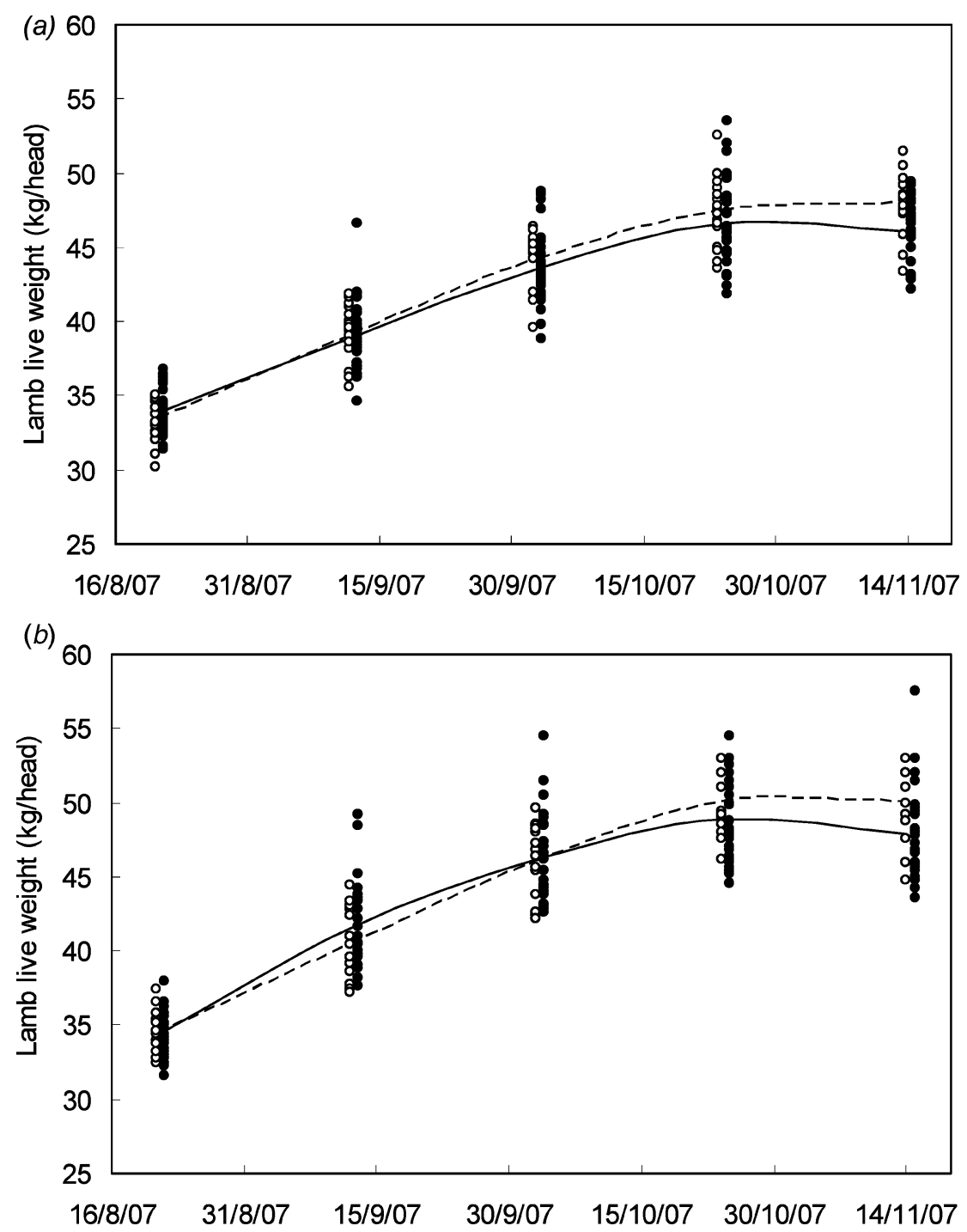

Figure 3. The lamb live weight of $(a)$ perennial pastures and $(b)$ annual pastures from August to November 2007 for the limed $(\bullet)$ and unlimed (o) pastures at Book Book, New South Wales, Australia. Solid and dashed lines are the fitted splines for lamb live weight per head of the limed and unlimed pastures.

likely associated with improved botanical composition of the limed pastures as there were significantly higher proportions of desirable species on the limed treatments than unlimed treatments for both perennial and annual pastures (Figure 2). This is consistent with studies on acid soils in New Zealand (O' Connor and Edmeades, 1984). As a result, the limed pastures carried $26.3 \%$ more stock than the unlimed pastures, hence producing more lamb live weight gain on per hectare basis. Li et al. (2006) also stated that the increased live weight and wool production on the limed 
treatments were attributable to a combination of increased pasture production and improved pasture quality at the same site.

\section{Prime lamb live weight gain on perennial and annual pastures}

Perennial pastures have potential advantages over annual pastures for animal production, such as a more even yearly feed supply and a longer growing season that could favour sheep production. Perennial pastures can also have high quality feed that could be beneficial to livestock production and sufficient to finish lambs in late spring. However, no live weight production advantage was recorded between perennial and annual pastures during the experimental period in the present study. In fact, lambs on the annual pastures had significantly higher live weight gains than those on perennial pastures during the first two grazing cycles. This was probably due to the rapid response of annual species, especially barley grass, to rainfall early in the season. In the perennial pastures, the annual components, such as subterranean clover, did respond to rainfall quickly, but for more consistent growth of the perennial components there needs to be a continuous supply of water from the soil profile.

This site had experienced several years of drought since the pastures were reestablished in 2004. The soil profile was assumed to be virtually empty of water to depth. The extremely dry conditions in August and September 2007 worsened the situation. As a result, lambs lost weight on the perennial pastures and just maintained live weight on the annual pastures. More seasons with normal or above average rainfall are needed to investigate if there is an advantage for animal production on perennial over annual pastures.

Nevertheless perennial pastures are often promoted for their environmental benefits as they can use soil $\mathrm{N}$ and water more efficiently, hence reducing the rate of acidification and the risk of dryland salinity in the high rainfall zone of southeastern Australia. At the study site, significant rainfall later in spring stimulated significant pasture growth in the perennial pastures, but not in the annual pastures (data not shown), showing that perennial pasture species can efficiently use out-of-season rainfall. Summer rainfall on annual pastures only stimulates growth of summer weeds, and/or refilling of the soil profile with water, a process that can promote the recharge of ground water in the following winter. Similarly, Scott et al. (2000) indicated that perennial species, particularly phalaris, could offer some scope for reducing soil acidification compared with annual pastures while maintaining a constant fixed stocking rate in southern NSW.

\section{Seasonal variation of prime lamb live weight}

Lamb live weight gain is dependent on the amount of feed-on-offer and feed quality, both of which often vary across seasons. Results in this experiment showed that lamb live weight increased substantially during the first two grazing cycles, with a live weight gain of 213-286 $\mathrm{g}_{\text {day }}{ }^{-1}$, then dropped to $128-190 \mathrm{~g} \mathrm{day}^{-1}$ at cycle 3 (Table 5). During the fourth grazing cycle, lambs just maintained their live weight on the unlimed treatments, but lost weight on the limed treatments even though low 
stocking rates were used during that period (Table 5). This variation in live weight gain followed the same pattern as pasture feed-on-offer, reflecting the rainfall that fell in those months. In a normal season, the typical perennial grass-based pasture in this region commonly reaches a peak growth rate of 60-100 $\mathrm{kg} \mathrm{DM} \mathrm{ha}^{-1} \mathrm{day}^{-1}$ in spring (Avery et al., 2000). However, it was extremely dry in spring in 2007, especially in August and September with only $59 \%$ and $24 \%$ of long-term rainfall, respectively (Table 1). In addition, it was a one in a hundred year drought in 2006, with the site receiving only half of long-term rainfall. Thus, from October 2007 all pastures, including perennial pastures, started to dry out with an associated decrease in feed quality (Table 3), resulting in lower or negative live weight gain by the fourth grazing cycle. The practical message from these results is that lambs should be moved to a feedlot to finish, or at least should be supplied with supplementary feed, rather than being left to graze in a period of feed shortage. From a pasture management point of view, the pastures should be de-stocked during dry periods, particularly in spring and/or summer when plants are accumulating internal energy reserves.

Acknowledgments. The authors are grateful to Mr John Glendining, the manager of the property Brooklyn owned by the Hurstmead Pastoral Company, for the lease of the land and continuous support since 1991 and to Richard Lowrie for his technical assistance. The project was funded by NSW Department of Primary Industries with financial support from Australian Wool Innovation. Our thanks extend to Incitec-Pivot Pty Ltd for supply of fertilizers and Omya Australia Pty Ltd for supply of limestone.

\section{REFERENCES}

Avery, A. L., Michalk, D. L., Thompson, R. P., Ball, P., Prance, T., Harris, C. A., FitzGerald, D. W., Ayres, J. F. and Orchard, B. A. (2000). Effects of sheep grazing management on cocksfoot herbage mass and persistence in temperate environments. Australian Fournal of Experimental Agriculture 40:185-206.

Bircham, J. S. and Crouchley, G. (1976). Effects of superphosphate, lime, and stocking rate on pasture and animal production on the Wairarapa plains. I. Pasture production and botanical composition. New Zealand fournal of Experimental Agriculture 4:57-63.

Bircham, J. S., Crouchley, G. and Wright, D. F. (1977). Effects of superphosphate, lime, and stocking rate on pasture and animal production on the Wairarapa plains. II. Animal production. New Zealand fournal of Experimental Agriculture 5:349-355.

Edmeades, D. C., Pringle, R. M., Shannon, P. W. and Mansell, G. P. (1984). Effects of lime on pasture production on soils in the North Island of New Zealand. 4. Predicting lime responses. New Zealand fournal of Agricultural Research 27:371-382.

Gilmour, A. R., Cullis, B. R., Welham, S. J. and Thompson, R. (2006). ASReml User Guide, Release 2. London: VSN International Ltd.

Hochman, Z., Osborne, G. J., Taylor, P. A. and Cullis, B. R. (1990). Factors contributing to reduced productivity of subterranean clover (Trifolium subterraneum L.) pastures on acidic soils. Australian fournal of Agricultural Research 41:669-682.

Hooper, S., Blias, A. and Ashton, D. (2003). Australian prime lamb industry 2003. ABARE Research Report. Australian Bureau of Agricultural and Resource Economics, Canberra, Australia.

Kopke, E., Young, J. and Kingwell, R. (2008). The relative profitability and environmental impacts of different sheep systems in a Mediterranean environment. Agricultural Systems 96:85-94.

Li, G. D., Helyar, K. R., Conyers, M. K., Gullis, B. R., Cregan, P. D., Fisher, R. P., Castleman, L. J., Poile, G. J., Evans, C. M. and Braysher, B. (2001). Crop responses to lime in long-term pasture-crop rotations in a high rainfall area in south-eastern Australia. Australian fournal of Agricultural Research 52:329-341. 
Li, G. D., Helyar, K. R., Evans, C. M., Wilson, M. C., Castleman, L. J., Fisher, R. P., Cullis, B. R. and Conyers, M. K. (2003). Effects of lime on the botanical composition of pasture over nine years in a field experiment on the south-western slopes of New South Wales. Australian fournal of Experimental Agriculture 43:61-69.

Li, G. D., Helyar, K. R., Conyers, M. K., Castleman, L. J., Fisher, R. P., Poile, G. J., Lisle, G. J., Cullis, B. R. and Gregan, P. D. (2006). Pasture and sheep responses to lime application in a grazing experiment in a high-rainfall area, south-eastern Australia. II. Liveweight gain and wool production. Australian fournal of Agricultural Research 57:1057-1066.

O' Connor, M. B. and Edmeades, D. C. (1984). A summary of MAF trials of the effects of lime on animal production. In Proceedings of a Workshop on Lime in New Zealand Agriculture, 17-19 (Eds B. L. J. Jackson and D. C. Edmeades). Hamilton, New Zealand: New Zealand Ministry of Agriculture and Fisheries.

Ridley, A. M. and Coventry, D. R. (1992). Yield responses to lime of phalaris, cocksfoot, and annual pastures in north-eastern Victoria. Australian fournal of Experimental Agriculture 32:1061-1068.

Scott, B. J., Ridley, A. M. and Conyers, M. K. (2000). Management of soil acidity in long-term pastures of south-eastern Australia: a review. Australian fournal of Experimental Agriculture 40:1 173-1198.

Shannon, P. W., Pringle, R. M., Mansell, G. P. and Edmeades, D. C. (1984). Effects of lime on pasture production on soils in the North Island of New Zealand. 2. The nature of seasonal pasture growth responses to lime application. New Zealand Fournal of Agricultural Research 27:357-361.

Yeates, J. S., McGhie, D. A. and Wilson, I. R. (1984). Soil acidity on high rainfall pasture. Fournal of Agriculture Western Australia 25:138-141. 
Reproduced with permission of the copyright owner. Further reproduction prohibited without permission. 